\title{
Structure and Reproductive Performances of Sahelian Goats in the Guera Region, in Central Chad
}

\author{
Logténé Youssouf Mopaté1, Vounparet Zeuh², Issa Youssouf Adoum³, \\ Djimtoloum Nadjissara ${ }^{1}$ \\ ${ }^{1}$ Livestock Research Institute for Development (LRID) ex Zootechnical and Veterinary Research Laboratory, \\ N'Djamena, Chad \\ ${ }^{2}$ Livestock Polytechnic Institute of Moussoro, Moussoro, Chad \\ ${ }^{3}$ University Institute of Sciences and Techniques, Abeche, Chad \\ Email: mopate.ly@gmail.com
}

Received 29 April 2014; revised 12 June 2014; accepted 28 June 2014

Copyright (C) 2014 by authors and Scientific Research Publishing Inc.

This work is licensed under the Creative Commons Attribution International License (CC BY).

http://creativecommons.org/licenses/by/4.0/

(c) (i) Open Access

\section{Abstract}

The purpose of the study was to establish the structure of monitored animal farms and determine reproductive parameters of Sahelian goats in the Guera Region, in Central Chad. Data were collected through longitudinal survey in 27 observatory farms during three years using goats identified by numbered ear tags. The herds were composed on average of about $71 \%$ of females. The age pyramid covering all years showed a significant number of males aged between 0 - 1 year and perceptible fall thereafter. However, some stability was observed in the class of the 2 - 8 years old among females. The frequencies of accumulated kiddings showed that $44 \%$ of births occurred in the rainy season against $28 \%$ respectively in the cool dry and hot dry seasons. Obtained reproduction parameters were: a sex ratio of 0.51 in favor of males, a kidding interval of 10.6 months with significant differences $(P<0.05)$ according to the rank of birth, an age at first kidding of 16.5 months for females born in monitoring and an age of $\mathbf{2 0 . 3}$ months for all first-kidding, giving an apparent fertility rate of $145 \%$, a fecundity rate of $116 \%$ and an abortion rate of $2 \%$. The composition and structure of herds have highlighted the importance of females to ensure the reproducibility of goat production systems. The determined reproduction parameters are references for actions to improve goat rearing in this area.

\section{Keywords}

Breeding, Goats, Structure, Reproduction, Sahel Zone, Guera, Chad 


\section{Introduction}

The severe droughts recorded during the past three decades (1970, 1980 and 1990) have compelled to put back on the agenda the rearing of goats in the Sahel. The capacity for the adaptation and selection of fodder resources of these animals in harsh environments contribute to identify them as choice livestock for this area [1]-[3]. Small ruminants such as goats provide breeders a substantial income from the sale of live animals and milk. In addition to income, the consumption of milk and meat improves the food diet of the pastoralists, because they are a significant protein source. These facts are shared by different authors [4]-[7] who note that the sustainable development of goat production is a means to improve the quality of life in developing countries, among the needed production parameters to know those of reproduction rank prominently in order to lead any intervention.

Chad had 9.9 million s mall ruminants in 2011, including about 3.1 million sheep and 6.8 million goats [8]. The practice of conducting these animals is in pastoralism, nomadic or sedentary modes. These rearing methods are the effect of the existence of three major geo-climatic zones (namely the Saharan, the Sahelian and the Sudanian zones). There are two breeds of goats in Chad, of which the Sahel goat or Sahelian goat and the Djallonké-type Sudanian goat, sometimes called Kirdi goat or Kirdimi [1] [9]-[11]. The separation zone between the two races is the 12 th parallel north latitude. The northern zone is the area par excellence of the Sahelian goat breed. Studies to determine the production parameters of goats were most often carried out in a timely manner in Chad [1].

The purpose of this work was to show the evolution of the size, composition and structure of herds and the reproductive parameters during the three years (2010-2012) of tracking goats in the region of Guera, in the middle belt of Chad.

\section{Materials and Methods}

\subsection{Study Site}

The study was conducted in goat farms in the Districts of Bitkine, Mongo and Mangalmé in Guera. The locations by GPS (Global Positioning System) coordinates are 11 ${ }^{\circ} 56^{\prime} 18^{\prime \prime}$ North Latitude and 18 $16^{\circ} 11^{\prime \prime}$ East Longitude for Bitkine, $12^{\circ} 09^{\prime} 30^{\prime \prime}$ North latitude and 18 40'30" East longitude for Mongo and 12 $21^{\circ} 04^{\prime \prime}$ and 19 $36^{\prime} 01^{\prime \prime}$ for Mangalmé. The study site is a transit area for many pastoralists moving towards the southeast (plains of Salamat) and the south. Being a rocky land by nature, it also hosts some pastoralists moving for new pastures for a longer or shorter period. This situation can lead to competition for scarce fodder resources along the paths followed in the area during the dry season.

\subsection{Sampling and Data Collection Methods}

A network of observatory farms comprising 27 herds spread over the three above mentioned Districts was established. Only volunteer farmers to collaborate in monitoring activities and settled in villages along the main permanent roads (for accessibility) were selected. The animals were identified individually using numbered ear tags. The age of the animals has been identified on the basis of tooth wear coupled with the breeder's declaration. Monitoring was introduced in the last quarter of 2009. This period was devoted to the training of investigators in collecting and entering data, which were not taken into account later on. Only data collected from January 2010 to the end of December 2012 were considered. The frequency of morning visits was twice a month for kids aged between 0 - 2 months, and once a month thereafter. The breeders as sist the investigators in gathering information. In order to keep them until the end of the visit, some treatment limited to the strict minimum is administered to sick animals at the end of the visit.

\subsection{Data Analysis}

The file of r ecorded kiddings d uring monitoring was ex tracted from the co mmon $\mathrm{d}$ ata $\mathrm{b}$ ase and exported to SPSS for processing [12]. First, a flat and cross sorting is made. Calculated reproductive parameters were seasonal frequencies of kidding, sex ratio, kidding interval, fertility (precocity and fertility rates), fecundity, prolificacy and abortion rates. Kiddings were grouped by season and year to highlight the changes. Depending on the site location, the seasons were grouped as follows: the cool dry season (CDS) lasting four months (November, December, January and February); the hot dry season (HDS) from March to June and the rainy season (RS) from July to October. Subsequently, a v ariance analysis was performed to highlight the significant differences in the 
average level of $5 \%$. Calculated reproductive parameters were:

o The sex ratio defined as the ratio of males and females at kidding on total registered births;

o The interval between kiddings is the time interval (in days or months) between two kidding events;

o Age at first kidding (in days or months) which is also referred to as earliness;

o The prolificacy rate or brood size is the number of offspring born (alive or dead) at the end of gestation;

0 The fertility rate defined as the ratio between the number of kiddings during the period on the number of reproductive animals in herds;

o The abortion rate, which is the ratio between the numbers of recorded abortions in the farms on the number of kiddings during the period under consideration.

\section{Results and Discussion}

\subsection{Changes in Herd Sizes, Structure and Composition}

Variation in quantity per annum indicated a gradual increase in the number of animals being monitored. The numbers were 714 heads in 2010, 1307 in 2011 and 1435 in 2012.

Overall, the herds were composed on average of about $71 \%$ of females, representing $75.4 \%$ in $2010,69.8 \%$ in 2011 and $66.6 \%$ in 2012 .

The pyramids for all years highlighted : a substantial number of males in the $0-1$ year age group, a drastic fall in the 1 - 2 years age group in 2010 (Figure 1), less than half in 2011 (Figure 2) and noticeable in 2012 (Figure 3). Apart from the year 2012, the number of males aged between $2-3$ years has been notoriously low. However

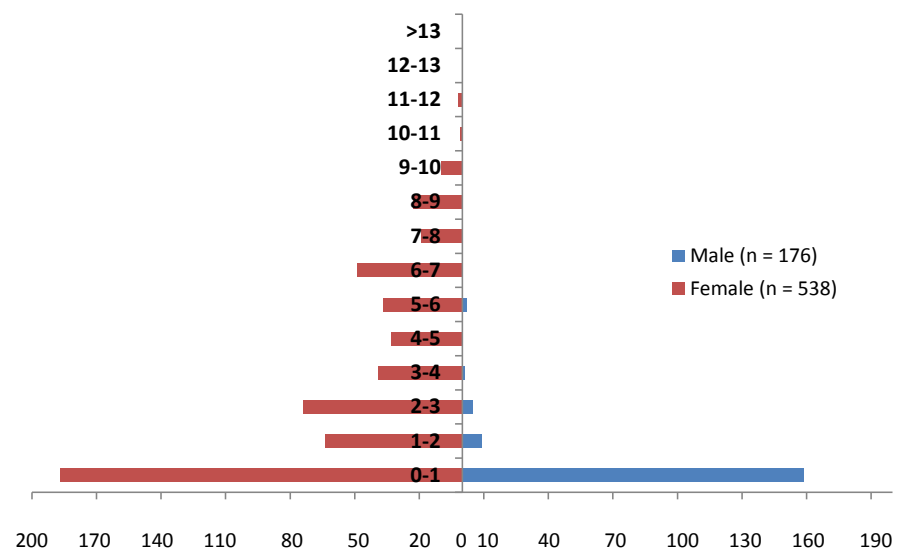

Figure 1. Age p yramid of $\mathrm{S}$ ahelian g oats monitored in 2010 in the Guera region (Chad).

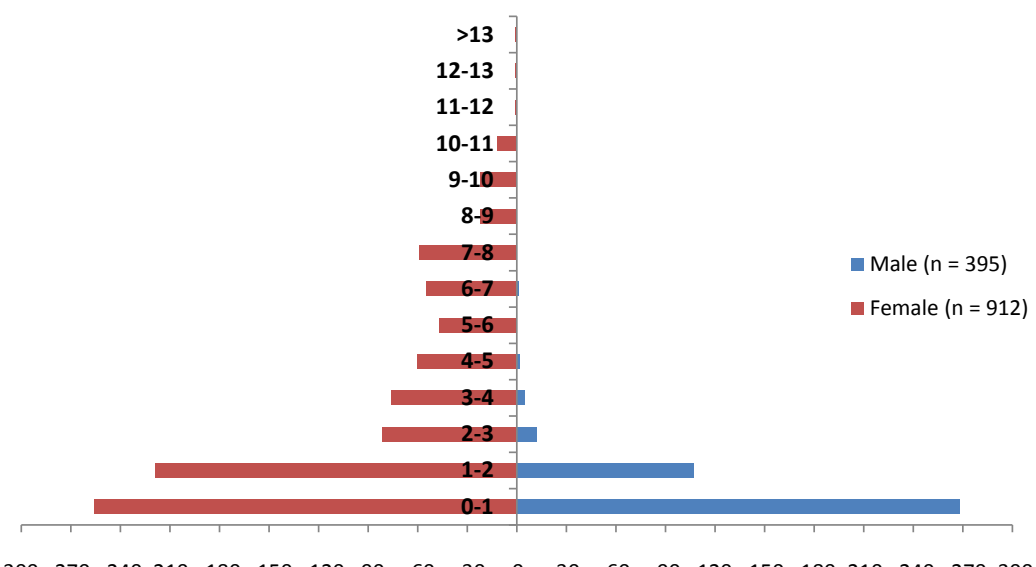

$\begin{array}{lllllllllllllllllllll}300 & 270 & 240 & 210 & 180 & 150 & 120 & 90 & 60 & 30 & 0 & 30 & 60 & 90 & 120 & 150 & 180 & 210 & 240 & 270 & 300\end{array}$

Figure 2. Age pyramid of Sahelian goats monitored in 2011 in the Guera region (Chad). 


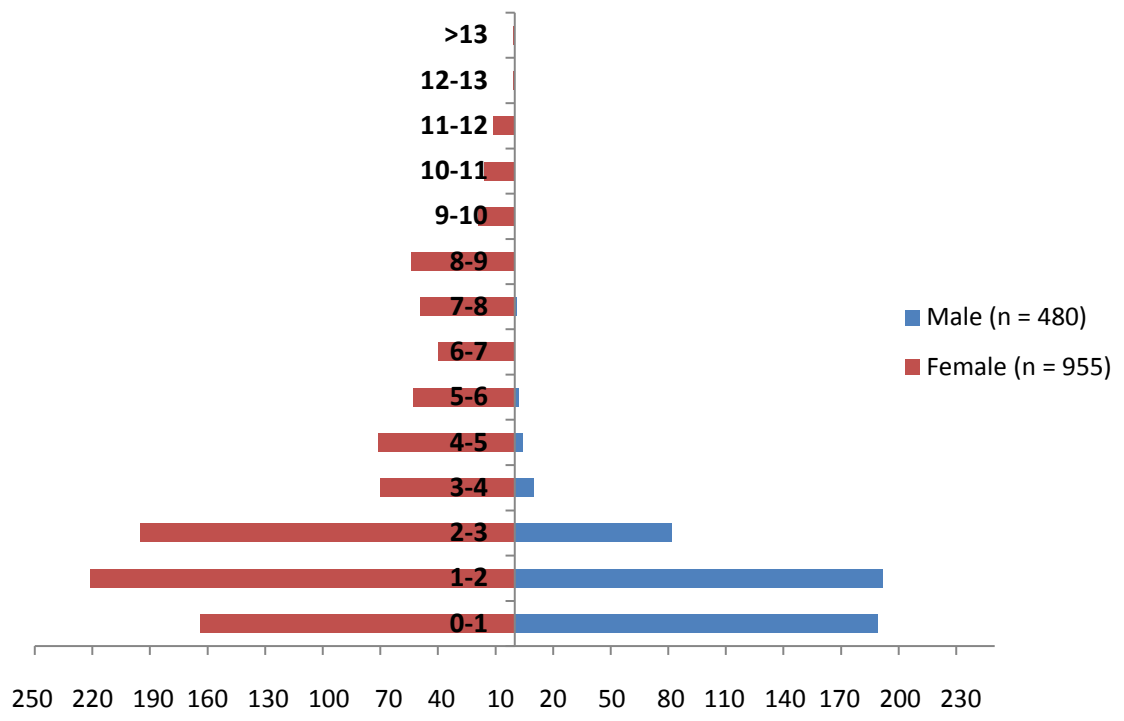

Figure 3. Age pyramid of Sahelian goats monitored in 2012 in the Guera region (Chad).

among females, the downfall trend in numbers started as from the second year for 2010 and 2011. The interval of 2 - 8 years brought together the core of breeding animals which accounted for $47 \%$ in $2010,41 \%$ in 2011 and $50 \%$ in 2012 . Beyond the ninth year age, the number of females has dropped considerably.

The variation in herd sizes shows an increase in the number of animals under monitoring, linked to some new breeders identified in 2010 but also to the inputs by the kiddings, the purchases and by a fall in mortality of kids more sensitive to diseases. The support provided to breeders through some care for sick animals had positive effects by helping to increase the number of goat farms being monitored.

An examination of the herd structure shows a d rastic drop in males after three years. This decrease is attributable to their more intense trading (sales and consumption) than females. Every male present in flocks beyond 2 years is either in reproductive activity or an animal considered as savings any time. The observed accumulation of females in flocks in the $2-8$ years range demonstrated the reproducibility of the rearing system provided primarily by breeding females. Sustainability of breeding depends more on these females. The considerable drop of the females after 9 years shows that the reforms are started. These results are comparable to the observations obtained in the Sahelian zone of Chad [13].

\subsection{Reproductive Performances}

\subsubsection{Kidding Frequencies}

According to the years, the variations of the relative frequencies of 1,301 cumulated kiddings were $31 \%$ in 2010 , $40 \%$ in 2011 and $29 \%$ in 2012.

In 2010, two peaks of kidding were recorded: the first one corresponding to the births occurring in the dry season happened in March (13.3\%) and May (13.6\%). The second peak occurs in the rainy post-rainy season. It was concentrated in four months (August, September, October and November) with frequencies far above $10 \%$. The maximum of $14.2 \%$ was noted in November.

In 2011, two peaks were also observed with one in a dry season only in May (11.3\%) greater than $10 \%$ and the second in September (16\%) and October (22.7\%), which has been the ever unequaled maximum during three years of follow-up.

In 2012, the level of kidding was low during the dry season. Only in January was reached the level of $8 \%$. However during the rainy and post rainy seasons, kidding frequencies were consistent around $13 \%$ over four months (September, October, November and December).

Overall during the three years of effective monitoring, the cool dry season and the hot dry recorded $28 \%$ of kidding each and the rainy season $44 \%$, which was significantly higher $(\mathrm{p}<0.05)$. The breakdown per year and season ha s confirmed the i mportance of ki ddings o ccurring during the $r$ ainy season (Figure 4). The kidding rates in cold dry season were not significant over the three years. On the other hand in season dry hot, the births 


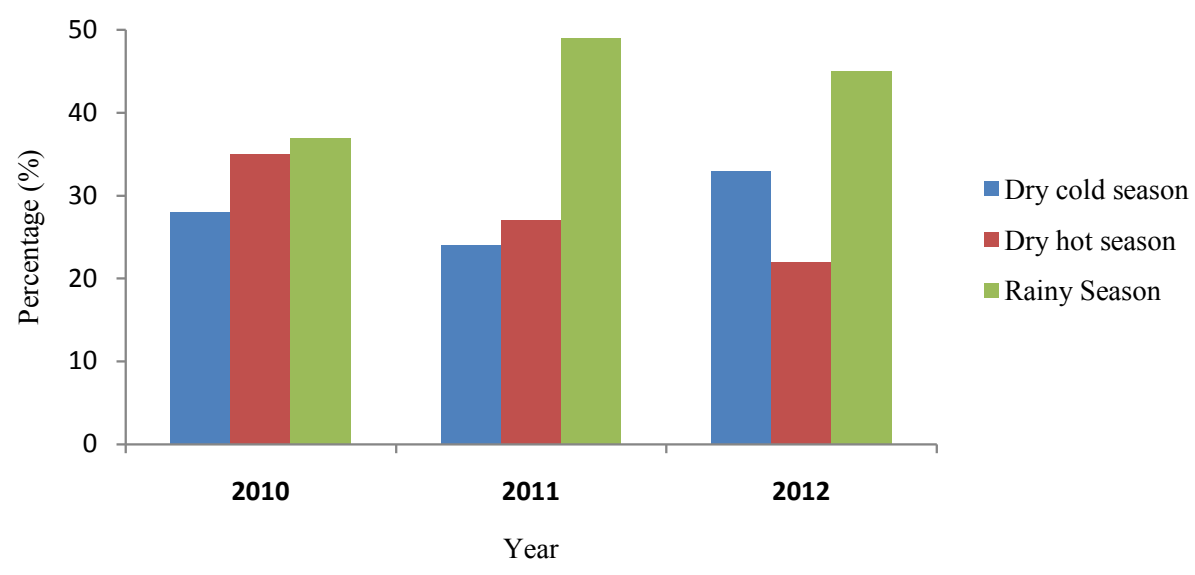

Figure 4. Changes in the relative s easonal kidding frequencies of the $\mathrm{S}$ ahelian $\mathrm{g}$ oats in the Guera Region (Chad).

in 2010 were significantly higher $(\mathrm{p}<0.05)$.

The level of kidding is linked either to the supply of fodder resources along the pathways or to the complementation provided to female at the end of the dry season [14]-[16]. The peak in March and May correspond to the moment when females are in heat during the harvest period occurring in October, November and December. In Orissa (Indian), the majority of goats comes into heat during Mars, April, May and June which resulted in 46\% of goats giving birth during September to November [17]. Others authors observed that $48.95 \%$ of the births were recorded between October and February [16].

\subsubsection{Reproductive Parameters}

The sex ratio at parturition of 0.51 for males and 0.49 for females of our study was approximately the same as those recorded during four years of follow-up among the Sahelian goats in Dourbali and Massakory areas (0.50) in $C$ had [18]. These s ex $r$ atios r esulting from longitudinal s tudies have d emonstrated cer tain $p$ arity b etween males and females at kidding. However, the results of random surveys show a sex ratio at parturition in favor of females $(0.53)$ [1].

The mean of kidding interval (KI) was $318 \pm 12$ days representing about 10.6 months. Significant differences $(\mathrm{P}<0.05)$ according to the kidding rank $(\mathrm{KR})$ were observed (Table 1$)$. In addition, observations have shown that the KI decreases in the opposite direction of the KR increase. Otherwise, more the goats have a high KR, more the $\mathrm{KI}$ is reduced.

The kidding interval obtained ( 318 days or 10.6 months) was higher than observations made in station (261 days) [19] and on the outskirts of N'Djamena (272 days) [20]. However, it was comparable to the results of Massakory (10.9 months) and Dourbali (10.7 months) [18]. These results highlight the impact of diet in improving reproductive parameters. Indeed, on site the feed of goats is better, whereas in suburban areas, the sale of goat milk to urban collectors which is a common practice requires the farmers' special attention to feeding goats [21]. In the Guera Region as well as in Massakory and Dourbali, animals only feed on natural pastures, resulting in higher KIs than those on the station and in the suburban area. The decrease of kidding interval contrary to the increase of kidding rank indicates an increase in fertility of goats with age. Females which have a big gap between two kidding intervals or late ages at first kidding, may have aborted during that period. This helps to explain the heterogeneity of the results obtained.

The average age at first kidding was $495 \pm 15.2$ days or 16.5 months among 107 females born during the monitoring. With a gestation period of 05 months, these females had their first fertilizing projection (first pregnancy) at about 11 months. For all females having given birth for the first time, the average age was 608 days or 20.3 months. This involves first fertilizing mating occurring at about 15 months. Different precociousness between goats born during monitoring and all first kidding events might be explained by the accuracy of the dates of birth. Among the formers, dates of birth are well known. In contrast with the latter, the double age estimation through using the memory of the animal breeder and an examination of tooth wear leads to inaccurate age of the animals. The survey of the career of Sahelian goats carried out using this method has determined an age at first pregnancy of 14.5 months or 19.5 for age at first kidding [1], close to our results (20.3 \pm 10 months). It was the 
Table 1. Change in kidding intervals depending on the kidding ranking of Sahelian goats in the Guera Region (Chad).

\begin{tabular}{ccc}
\hline Rank of kidding & Number of observation & Average kidding interval (in days) \\
\hline 1 & 115 & $346 \pm 128^{\mathrm{A}}$ \\
2 & 82 & $317 \pm 113^{\mathrm{B}}$ \\
3 & 76 & $307 \pm 117^{\mathrm{C}}$ \\
4 & 84 & $329 \pm 131^{\mathrm{D}}$ \\
5 & 64 & $322 \pm 119^{\mathrm{E}}$ \\
6 & 40 & $288 \pm 95^{\mathrm{F}}$ \\
7 et + & 51 & $237 \pm 95^{\mathrm{H}}$ \\
\hline
\end{tabular}

Means in the same column with different superscripts are statistically different $(\mathrm{p}<0.05)$.

same age at first kidding established for all females in goat breeding monitored at Dourbali being $19.6 \pm 10.3$ months, representing a first pregnancy at 14 months [18].

As for the rate of apparent fertility, it was $145 \%$ (1.45), that of fertility $165 \%$ (1.65), of prolificacy $116 \%$ or 1.16 produced in average of and that of abortion $2 \%$. The fertility rate observed in the Guera Region was higher than the values obtained by cross-sectional survey on the Chad Sahelian goats [1], including those in the Batha $(109 \%)$ and Assalé (104\%) regions. It is equivalent to the rate observed by the same author in relation to the Djallonké type Kirdimi goats, in the Sudanian part of the country. However, it is less than the $171 \%$ value observed on station among Sahelian goats in Massakory [19]. As for the rate of prolificacy obtained in the Guera Region, it was higher than the data reported in B atha (108\%) and Assalé (112\%) for Sahelian goats in others areas of Chad [1]. It should be noted that fertility and prolificacy, although related to species and breeds, a re well under the influence of animal husbandry conditions including feeding. It is the same for other reproduction parameters, which will be higher or lower depending on whether the animals live in areas where food resources are abundant or not.

\section{Conclusion}

The study established for the first time through longitudinal survey of the structure of goat herds and determined reproductive parameters of goats in the Guera Region, in the Sahelian strip of Chad. The herd composition and structure have highlighted the importance of females to ensure the reproducibility of go ats rearing in the area. Kidding spread throughout the year and this indicates that the Sahel goats are not seasonal, which is an advantage in the development of production of these animals. However, a significant number of kidding in the rainy season, a period when feeding conditions are better on rangelands is observed. The determined reproduction parameters are references which enable developing strategies for the valorization and improvement of goat farming in this area. Reproduction control based on knowledge of such performances is a prerequisite for the numerical growth of the herds. In addition, further studies on non-genetic factors such as husbandry practices and major diseases control would help to better understand the production of goats in the Guera Region.

\section{References}

[1] Dumas, R. (1980) Contribution à l'étude des petits ruminants du Tchad. Revue d'Elevage et de Médecine Vétérinaire des Pays Tropicaux, 33, 215-233. http://remvt.cirad.fr/revue/notice fr.php?dk=455021

[2] Sandabe, U.K. and Chaudhary, S.U.R. (2000) Effect of Environmental Temperature on Some Biochemical Values in Female Sahel Goats. Pakistan Veterinary Journal, 20, 10-12.

http://www.pvj.com.pk/archive/Volume_20_Issue_1_2000.htm

[3] Sangaré, M. (2009) Intérêts et limites de l'élevage caprin dans les écosystèmes fragiles et propositions d'amélioration: Cas des systèmes d'élevage sahélien du Mali. Options Méditerranéennes, Changes in Sheep and Goat Farming Systems at the Beginning of the 21st Century, A 91, 151-156.

[4] Devendra, C. (1980) Potentials of Sheep and Goats in Less Developed Countries. Journal of Animal Science, 51, 461473. http://www.journalofanimalscience.org 
[5] Raun, N.S. (1982) The Emerging Role of Goats in World Food Production. Proceedings of the 3rd International Conference on Goat Production and Diseases, Tucson, 5-9 January 1982, 133-141.

[6] Wilson, R.T. (1982) The Economic and Social Importance of Goats and Their Products in the Semi-Arid Arc of Northern Tropical Africa. Proceedings of the 3rd International Conference on Goat Production and Diseases, Tucson, 1015 January 1982, 186-191.

[7] Devendra, C. (2013) Investments on Pro-Poor Development Projects on Goats: Ensuring Success for Improved Livelihoods. Asian-Australian Journal of Animal Science, 26, 1-18. http://www.ajas.info/

[8] DESPA (Direction des Études, des Statistiques, de la Programmation et des Archives) (2011) Rapport annuel des statistiques. Ministère du Développement Pastoral et des Productions Animales, 52.

[9] Receveur, P. (1943) Tchad et élevage. Projet d'organisation et d'orientation de l'élevage au Tchad (AOF).

[10] Zeuh, V. and Bourzat, D. (1993) Caractérisation génétique des populations caprines au Tchad: Résultats préliminaires des caractères phénotypiques et biométriques. Actes du Comité Scientifique de Garoua, session du 15 au 20 Février 1993, 51-72.

[11] Bourzat, D., Souvenir Zafindrajoana, P., Lauvergne, J.J. and Zeuh, V. (1993) Comparaison morphobiométrique des chèvres au Nord Cameroun et au Tchad. Revue d'Elevage et de Médecine Vétérinaire des Pays Tropicaux, 46, 667-674. http://remvt.cirad.fr/revue/notice_fr.php?dk=398736

[12] SPSS (2009) Statistical Package for Social Sciences. Version 17.0, SPSS Incorporated, Illinois.

[13] Dumas, R. (1977) Etude sur l'élevage des petits ruminants au Tchad. Institut d'Elevage et de Médecine Vétérinaire des pays Tropicaux (IEMVT)/Banque Internationale pour la Reconstruction et le Développement (BIRD).

[14] Kuralkar, S.V., Ali, S.Z. and Takarkhede, R.C. (2002) Kidding and Growth Pattern of Kids under Organized Farm Conditions. Indian Journal of Small Ruminants, 8, 149-152. http://www.indianjournals.com/ijor.aspx?target=ijor:ijsr \&volume $=8 \&$ issue $=2 \&$ article $=019$

[15] Kumar, A., Maity, S.B., Kushwaha, B.P. and Mahanta, S.K. (2010) Effect of Season on Kidding and Birth Weight in Bundelkhandi Goats. Indian Veterinary Journal, 87, 378-379. http://ivj.org.in

[16] Harikrishna, Ch., Raghunandan, T. and Gnana Prakash, M. (2013) Effect of Season on Kidding and Birth Weight in Osmanabadi Goats Reared in an Organized Farm. International Journal of Livestock Research, 3, 84-88. http://www.ijlr.org

[17] Singh, B.S.P., Rao, P.K., Patro, B.N., Dash, S.K. and Panda, P. (2008) Genetic Analysis of Indigenous Goats of Keonjhar District of Orissa. Indian Veterinary Journal, 85, 843-845.

[18] Imadine, M., Mopaté, L.Y. and Idriss, A. (1995) Etude dynamique des systèmes de production animale (Bovins, Caprins et Ovins) à Dourbali et Massakory au Tchad: Productivité et contraintes sanitaires. Rapport Technique, Laboratoire de Farcha, N'Djaména. 70.

[19] Bertaudière, L. (1977) Aspects de la reproduction et aptitude laitière chez la chèvre du Sahel (chèvre de Massakory). Rapport annuel du Laboratoire de Farcha, 19-48.

[20] Lancelot, R., Mopaté, L.Y., Imadine, M., Ickowicz, A. and Faye, B. (1992) Utilisation d'une enquête écopathologique pour l'aide au choix des mesures d'amélioration de la productivité des chèvres en zone sahélienne du Tchad. Rapport Technique, Laboratoire de Farcha, N'Djaména, Tchad, 25.

[21] Koussou, M.O. and Mopaté, L.Y. (2006) Le bassin d'approvisionnement de la ville de N'Djaména en lait: Zonage et typologie des élevages laitiers. Revue Africaine de Santé et de Production Animales, 4, 39-44.

http://www.eismv.org/Publications.html 
Scientific Research Publishing (SCIRP) is one of the largest Open Access journal publishers. It is currently publishing more than 200 open access, online, peer-reviewed journals covering a wide range of academic disciplines. SCIRP serves the worldwide academic communities and contributes to the progress and application of science with its publication.

Other selected journals from SCIRP are listed as below. Submit your manuscript to us via either submit@scirp.org or Online Submission Portal.
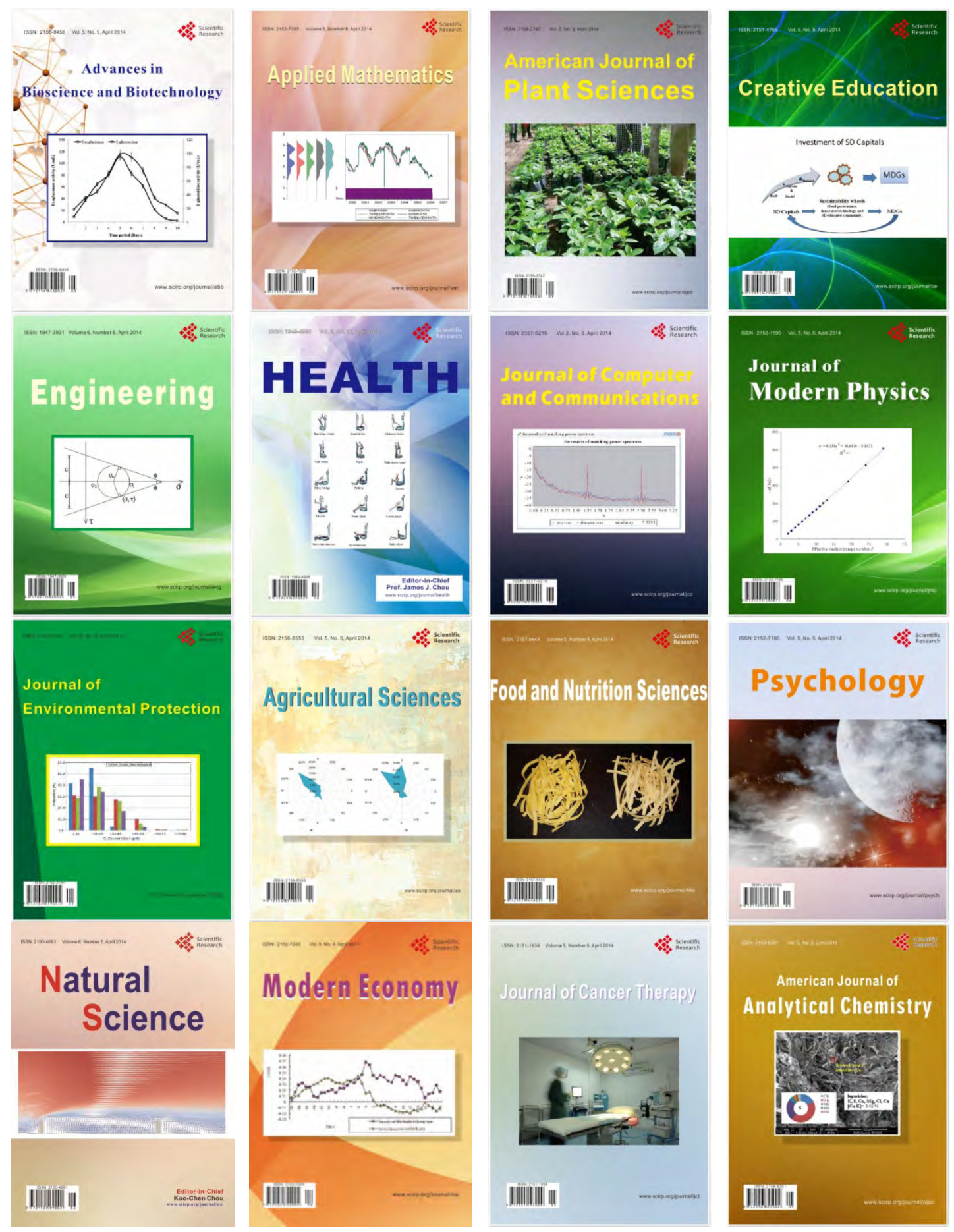

Analytical Chemistry

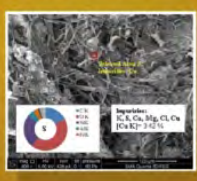

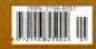

